\title{
Megachurches and 'Reverse Mission'
}

\author{
Richard Burgess
}

\section{1 \\ Introduction}

The presence of African Christian communities in Europe and North America represents one of the most significant developments within world Christianity over the past three decades (Adogame 2013; Gornik 2011; Hanciles 2008; Olupona and Gemignani (eds.) 2007; Ter Haar 2001). In Europe, African churches are becoming an increasingly important addition to the urban religious landscape, especially in globalising cities such as London, Amsterdam and Berlin. The majority are Pentecostal or Charismatic, which represents the fastest-growing Christian tradition worldwide (Johnson 2013). Gerrie Ter Haar (2001: 13) regards it as a fresh phase in European religious history, adding a new dimension to the multicultural society which Europe has become since the end of the Second World War. Whereas in the past, mission has been understood as a movement from the North to the South, now it is happening in the opposite direction, a phenomenon commonly referred to as 'reverse mission' (Burgess 2011; Freston 2010; Koning 2009; Währisch-Oblau 2009).

This chapter examines 'reverse mission' as it relates to megachurches of Nigerian provenance. In the literature, megachurches are defined as Protestant churches having at least 2,000 attendees per week (Ellingson 2016; Thumma and Travis 2007). The field of megachurch studies originated in the USA, where the largest number of megachurches are located (Ellingson 2016; Thumma 1996; Thumma and Travis 2007). However, there is now a growing recognition that megachurches are a global religious phenomenon exerting significant social influence in urban contexts around the world (James 2015; Thumma and Bird 2015a). This has generated an emerging body of literature by scholars from across the academic disciplines, including social scientists, theologians and missiologists. Researchers have studied megachurches in North America, Europe, Asia, Africa, Latin America, and Australia (Asamoah-Gyadu 2015; Cartledge et al 2019; Chong 2015; Ellingson 2016; Fath 2008; Smith and Campos 2015; Thumma and Travis 2007; Vermeer 2015; Wade 2016). Nigeria hosts some of the largest megachurches in the world with multiple branches nationwide as well as in other African countries, North America and Europe. Nigerian Pentecostals 
have also planted some of the largest megachurches in Europe. The most wellknown are Sunday Adelaja and Matthew Ashimolowo, founders of the Embassy of the Blessed Kingdom of God for All Nations in Kiev and Kingsway International Christian Centre in London respectively (Asamoah-Gyadu 2005; Cartledge and Davies 2013). Significantly, seven out of the twelve megachurches in London were planted by Nigerians. ${ }^{1}$

While the USA has the highest number of megachurches, with an estimated 1,611 in 2011 (Bird and Thumma 2011), most of the world's largest churches are located in Africa, Asia and Latin America, reflecting the global shift in Christianity's centre of gravity southwards (James 2015; Thumma and Bird 2015a). Warren Bird's country-by-country list of global megachurches includes 33 megachurches with a weekly attendance of 20,000 and above in Asia, 19 in Africa, 15 in Latin America, and 15 in the USA. The world's largest megachurch is the Yoido Full Gospel Church in South Korea, with an estimated 480,000 attendees (Bird 2017). Winners' Chapel in Lagos, Nigeria, has the largest church auditorium in the world, the 50,400-seater Faith Tabernacle. Although they share family resemblances with their American kin in terms of their theology, architecture and programmes, many southern megachurches have flourished in ways that their more established counterparts have not (Richardson 2017). As Richardson (2017: 294) notes, these congregations, which are located in 'mega-cities' such as Seoul, Lagos and Rio de Janeiro, attract younger and poorer audiences than their American counterparts and often belong to transnational networks "that aim to replicate the success and growth strategies of the mother church".

The chapter begins with a discussion of the term 'reverse mission', a concept which has gained currency in the literature on transnational Pentecostal churches (Gerloff 2000; Ter Haar 2001; Währisch-Oblau 2009). Researchers have distinguished between the rhetoric of reverse mission and its reality on the ground (Freston 2010; Obinna 2014). The following section examines the phenomenon of reverse mission as its relates to megachurches in Nigeria and the Nigerian diaspora in Britain. Finally, the chapter explores the actual achievements of Nigerian Pentecostals against the background of European secularism. One of the issues raised in the literature on megachurches in Europe is whether their presence challenges the idea of secularisation (Richardson 2017; Vermeer 2015; von der Ruhr and Daniels 2012). The chapter considers whether the growth of Nigerian Pentecostals in Britain supports the idea that in certain European contexts religion may be gaining rather than losing

1 These are Kingsway International Christian Centre, Jesus House, Winners' Chapel, New Wine Church, Glory House, Victorious Pentecostal Assembly, and Christ Faith Tabernacle. 
strength in modern times. Studies of reverse mission sometimes measure success in terms of winning indigenous converts or adherents and consequently find diasporic churches wanting (Freston 2010; Währisch-Oblau 2009). As I will argue, the adoption of a broader conception of mission which includes social engagement enables a more nuanced assessment of their achievements. The chapter draws upon research conducted in Nigeria and Britain, which included interviews with Nigerian pastors, participant observation of Nigerian Pentecostal churches, and content analysis of media products. ${ }^{2}$

The term 'reverse mission' derives from mission studies and is closely linked to the evolving relationship between the global and local, a defining feature of late modernity. The predominant meaning of the term refers to the purported historic shift in the direction of mission. According to Paul Freston (2010: 155-156), this involves two main elements: a reversal in the geographical direction of mission and a reversal in the direction of 'colonisation', in other words an inversion of centre-periphery relations in Christianity, whereby the formerly colonised are now evangelising the former colonisers. Most commonly it is used to refer to the emergence of African, Latin American and Asian churches in Europe and North America and their aspirations to re-evangelise the former heartlands of Christianity, which are regarded as increasingly secular (Asamoah-Gyadu 2005; Ojo 2007). This reversal is said to owe its momentum to two historical coincidences: the shift in Christianity's centre of gravity southwards and the increase in transcontinental migrations from the non-Western world (Hanciles 2008). In the literature, the term 'reverse mission' has mainly been used of megachurches in Korea, Brazil, and Nigeria and their church-planting activities in Europe and North America (Burgess 2011; Freston 2010; Kim 2016; Oro 2014; Silva and Rodrigues 2013; Udotong 2010; Währisch-Oblau 2009).

The idea of reverse mission has gained currency in the media and academy largely due to the perceived decline in European Christianity compared to the religious vitality of the non-white Christian population, and by the presence of Muslim immigrants which has raised the question of Christianity's connection with European identity (Freston 2010: 154). However, Freston (2010: 160) regards it as a "discourse in search of reality", doubting the "capacity of diaspora

2 Most of the research for this chapter was supported by a grant from NORFACE and a grant from the John Templeton Foundation, which was administered through the Center for Religion and Civic Culture (University of Southern California). 
communities to act as missionaries to native populations". He suggests that the concept is popular with southern Christians because it is a way to "boost the self-image of postcolonial nations and their diasporas" (Freston 2010: 172). Similarly, Rebecca Catto (2008: 235, 220, 254) suggests that while the rhetoric of 'reverse mission' has grown in popularity in Britain, and exists in "attentiongrabbing pockets", it remains largely a discourse rather than a statistically demonstrable phenomenon. Asonzeh Ukah (2009) characterises Nigerian Pentecostal churches in Britain, such as the Redeemed Christian Church of God (RCCG), as "asylum Christianity", providing a safe haven for African migrants, rather than as examples of reverse mission. He suggests that the "remissioning rhetoric" provides "mechanisms to negotiate the hardships and deprivations that individuals encounter in the process of establishing themselves in Europe" (Ukah 2009: 125).

The presence of African churches in Europe's cities raises the question of the interplay between the local and global. In the literature on religious transnationalism, there is a growing interest in the way African Pentecostal churches in Europe are resacralising portions of the urban landscape (Adogame 2013; Eade 2017; Garbin 2013; Knibbe 2010; Krause 2008). Transnational movements such as African Pentecostal churches challenge the usual national frameworks for the scholarly study of religious movements. Some migrants remain strongly influenced by ties to their homelands or by social networks that transcend national borders (Levitt and Glick Schiller 2004; Wimmer and Glick Schiller 2003). The transnational character of diasporic churches is sustained by migrants who increasingly move between home and host countries, visiting family, engaging in business, and attending religious conferences (Burgess et al. 2010; Levitt 2001). Transnational networks are also reinforced by media technologies such as mobile phones, the Internet and Satellite TV.

\section{$3 \quad$ Nigerian Megachurches and Reverse Mission in Britain}

Bird's global megachurch survey lists 119 megachurches in Africa, of which nearly two-thirds are located in Kenya and Nigeria (Bird 2017). There are also Nigerian-initiated megachurches planted in other African countries. For example, Winners' Chapel boasts the largest congregations in Ghana, Kenya and Zambia (Gifford 2004, 2015). Overall there are 14 megachurches in Lagos, which represents one the highest concentrations of such churches in the world (Bird 2017 ; Richardson 2017). The largest are Deeper Life Bible Church $(65,000)$, Winners' Chapel (50,000), and the Redeemed Christian Church of God (RCCG) $\left(5^{0,000)}\right.$. Lagos metropolis is an increasingly fragmented and unregulated 
urban space characterised by a lack of basic infrastructure, traffic congestion, insecurity and a growing gulf between rich and poor (Marshall 2014; Ukah 2004; Ukah 2014). This has made it especially fertile ground for Pentecostal churches with their social support networks and promises of power to overcome sickness, poverty, unemployment and evil forces. The urban religious geography is dominated by a bewildering array of Pentecostal institutions occupying warehouses, office spaces, cinema houses, and purpose-built structures (Ukah 2004). A recent trend is the creation of Pentecostal 'cities' in the vicinity of Lagos, consisting of huge auditoriums, housing estates, banks, supermarkets, health centres, educational institutions and recreational facilities (Ukah 2014). RCCG's Redemption Camp has an auditorium that can accommodate one million worshippers.

Most Nigerian megachurches are affiliated to large Pentecostal denominations with multiple national and international branches. For example, RCCG, founded in 1952, has over 14,00o branches in Nigeria and branches in nearly 200 nations. ${ }^{3}$ The majority of RCCG churches outside Africa are located in Europe and the USA. ${ }^{4}$ Mountain of Fire and Miracles (MFM), founded in 1989, has over three hundred branches nationally, and branches in other African nations, 131 branches in Europe, 111 in the USA, as well as multiple branches in other African countries and Asia (Adogame 2005). ${ }^{5}$ Winners' Chapel has over 6,000 branches in Nigeria and congregations in 147 countries in Africa, Asia, Europe and the USA (Gifford 2015; Ojo 2006). ${ }^{6}$

Nigerians make up one of the largest transnational African communities in Britain, mainly due to Nigeria's status as Africa's most populous nation and its historic links to Britain as a former colony. Current estimates indicate that there were 191,183 Nigerian-born residents in the UK in 2011, up from 87,000 in 2001, with the large majority living in London. ${ }^{7}$ The spread of Nigerian Pentecostal churches to Britain must be understood within the context of social and religious developments in home and host countries. A relatively liberal British migration policy, combined with poor governance and a decline in educational

3 Ruth Gledhill, "Enoch Adeboye Steps Down As Head Of Redeemed Christian Church Of God In Nigeria”, 9 January 2017, Christianity Today, https://www.christiantoday.com/article/ enoch-adeboye-steps-down-as-head-of-redeemed-christian-church-of-god/103720.htm.

4 National Chairman of the Central Missions Board (RCCG), interview, 25/04/o9.

5 http://www.mountainoffire.org.uk/index.php/branches (accessed 11 April 2018); MFM USA Branches, http://mfmusa.org/branches/.

6 https://www.vanguardngr.com/2014/12/winners-chapel-has-six-million-members -spread-across-147-countries-oyedepo/

7 Based on the 2001 and 2011 census data. This does not include undocumented migrants and UK citizens of Nigerian descent. 
standards at home, resulted in a growing African migrant community, especially from Nigeria and Ghana. The first wave of African church planting in Britain followed the increase in immigration in the 1960s and consisted of mainly Aladura-type churches from Nigeria, transplanted to cater for their members in the diaspora (Gerloff 2000; Harris 2006). The second wave, which began in the 1980 , involved mainly Nigerian and Ghanaian neo-Pentecostals concerned with catering for members who had migrated to Britain at a time of economic decline at home (Osgood 2006). Church growth was stimulated by a conscious missionary agenda as Nigerian Christians, who had migrated in pursuit of education and employment, considered that God had given them a unique opportunity to bring the gospel back to those who originally provided it. Among the earliest transplants were branches of Nigerian megachurches such as Deeper Life Bible Church (1985) and the RCC G (1988). A more recent development saw individual Africans setting up their own independent congregations with no formal links to a sending denomination at home or in Britain. The majority were started by Nigerians or Ghanaians, and most were located in London. Examples of independent megachurches founded by Nigerians include Christ Faith Tabernacle (1989), Kingsway International Christian Centre (1992), Glory House (1993), New Wine Church (1993), and Victorious Pentecostal Assembly (2005). Meanwhile church-planting by megachurches in Nigeria continued apace as branches of MFM (2000) and Winners' Chapel (2003) were started initially in London but subsequently in other British cities. ${ }^{8}$

While the term 'reverse mission' was not explicitly used by my informants, the idea was implicit in some of their interview narratives. Pastor Olu first came to Britain as a student in 1994. He then returned to Nigeria where he became a pastor in the RCCG. In 1998, he again visited Britain and started a branch of the church in Birmingham. He explained the rationale behind this:

The story we heard was that Britain came to Africa to evangelise the place, brought the gospel, and whoever has sown deserves the right to reap. And because Britain has done this in the past, we are now looking at Britain as a place which itself needs to be evangelised. Many people no longer go to church in Britain. It is therefore the plan of the Redeemed Christian Church of God to do as much as they can to evangelise the land. What they have given to us in the past, bring it back to them. ${ }^{9}$

8 For the history of African churches in Britain, see Adedibu (2012); Osgood (2006).

9 Interview, 11/10/07. 
Here we see the historical dimensions of the reverse mission paradigm and its associations with the re-evangelisation of Britain, one motivation for which is gratitude to British missionaries for introducing the gospel to Africa. Pastor Andrew, another RCCG pastor, makes a connection between the erosion of Britain's Christian identity, its status as a former missionary-sending nation, and its loss of global prominence.

"Great Britain unfortunately is no longer great because all the things that made Britain great are now gone.... So wherever Redeemed goes, backed by the Holy Spirit, life will be breathed back into that place. If Great Britain embraces the church once again, and embraces God once again, all that was lost will be restored. The men of God who were missionaries all over the world, they came out from Britain, they fought for God. But now this generation has turned their back on God."10

What these narratives have in common is their projection of a particular image of Britain as a former missionary nation turned mission field. This functions as a rhetorical device, enabling pastors to legitimise their sense of mission to the host country. The image is restorationist: restoring the British church to its former glory and Britain as a Christian nation. An article in the RCCG's magazine Festival News also illustrates this restorationist agenda. Entitled "From City of Sin to City of God", it describes the ministry of the RCCG's Jesus House Aberdeen against the backdrop of an increasingly secular community: "Aberdeen.... was declared at the last UK National census as the most godless city in Britain.... The churches were being transformed into flats, restaurants, casinos, bars and night-clubs at an alarming rate.... Into this deteriorating and chaotic environment, God introduced the Redeemed Christian Church of God"." A central thrust of the article was to celebrate the acquisition by the RCCG of a disused Church of Scotland building in the heart of the city.

Concern over the conversion of church buildings into secular spaces and a desire to reverse this trend is a popular theme in Nigerian Pentecostal discourse. For instance, shortly after the church purchased the former Church of Scotland building, a message appeared on the its website, entitled "This Church building will not become another pub or casino or night club!"12 Another Nigerian pastor expressed similar concerns: "When I travel around any town or city, I see almost on every corner church buildings are empty; they are being turned into flats; they are being turned into nightclubs; they are being turned into

\footnotetext{
10 Interview, 16/02/08.

11 Ayo Adedoyin, "From City of Sin to City of God," Festival News (March 2008), 44-45.

12 www.jesushouseaberdeen.org. Accessed 12/12/o9.
} 
mosques". ${ }^{13}$ In his study of religious change in South West Wales, Paul Chambers (2006: 30) refers to the way abandoned church buildings "stand as mute witnesses to the decline of institutionalized religion" and "symbolic reminders" of a "rich religious past" as well as evidence of religion's loss of social and cultural significance. This stands in stark contrast to what Nigerian Pentecostals are used to back home where church buildings are springing up everywhere, and the only unused ones are those that are yet to be completed due to lack of money or derelict due to inter-religious conflict.

Transnational connections exert a strong influence on the religious practices of Nigerian megachurch transplants in Britain. This is exemplified by the RCCG, whose mission statement includes the goal to "plant churches within five minutes walking distance in every city and town of developing countries and within five minutes driving distance in every city and town of developed countries". ${ }^{14}$ The RCCG encourages members to plant churches wherever they are, thus fulfilling the divine promise given to its founder that the church would spread around the world before the Second Advent of Christ (Adedibu 2016). Asonzeh Ukah (2009: 117-118) identifies three ways RCCG congregations are founded outside Nigeria. First, a rich congregation in Nigeria could sponsor the establishment of a branch in Britain. Second, a member of RCCG who has migrated for work or study may start a church, which is incorporated into the RCCG family once it becomes viable.

Finally, a rich congregation in Britain can plant a church by commissioning one of its members. Transnational links between megachurch branches and their Nigerian headquarters are reinforced by visits from senior pastors in $\mathrm{Ni}$ geria, by the attendance of UK pastors at Nigerian programmes, and by the use of the media. For example, Daniel Olukoya, General Overseer of M FM, hosts an annual conference in London, which attracts over 3,000 people. MFM pastors in Britain also make regular visits to Nigeria to attend training events and prayer retreats. MFM services in Nigeria are streamed live on the Internet, and MFM devotional books, training manuals and DVDs are available for sale in UK branches. Significantly, most Nigerian churches have stronger links to West Africa and the USA than they do to church networks in the UK.

Due to the transnational flows of ideas, resources and people, Nigerian reverse mission churches, especially large congregations such as KICC and Jesus House London, share many of the features of their megachurch kin in Africa. As Asamoah-Gyadu (2015) notes, these include a charismatic and usually welleducated leadership, exuberant and affective worship styles, innovative use of

\footnotetext{
13 Interview, 16/02/o8.

14 See http://rccgint.org/vm.html. Accessed 08/10/o9.
} 
media technologies, the establishment of transnational networks including the formation of international branches, and an emphasis on success-oriented theologies. Thumma and Travis (2007), based on their research in the USA, discern four megachurch styles: Old Line/Programme-based; Seeker-Oriented; Charismatic/Pastor-focused; and New Wave/Re-envisioned. Nigerian megachurches, both at home and in the diaspora, fit the profile of Thumma and Travis' Charismatic/Pastor-focused megachurches. The most notable example is the RCCG, whose General Overseer, Pastor Enoch Adeboye, is well-known for his personal integrity, charismatic gifts of healing and prophecy, and teaching skills. He has been largely responsible for transforming the RCC G from a small, localised Pentecostal denomination in southwestern Nigeria to a movement of global significance (Burgess et al. 2010). To some extent, Adeboye's charismatic style and gifting are replicated in the ministries of some of the more successful RCCG pastors in Britain. This is partly explained, from a participant point of view, by the transfer of charismatic authority through the ritual of ordination, which is usually conducted by Adeboye himself. It is generally the case that larger parishes are led by men or women who possess charismatic healing and prophetic gifts, organisational and preaching skills (Burgess 2012).

An important debate in the literature on reverse mission is whether southern churches are succeeding in their ambitions to re-evangelise secular Europe (Burgess 2011; Catto 2008; Freston 2010). As suggested in the introduction, studies of reverse mission tend to measure success in terms of winning indigenous converts or adherents and consequently find diasporic churches wanting. This is based on a rather narrow conception of mission as evangelism and church-planting. Yet Nigerian Pentecostals in Britain often have a more holistic approach to mission, which includes evangelism and social action, and regard their movement as a significant social force capable of reversing the secularising tendencies of British society. This has driven some to embark on programmes of territorial expansion, not only through evangelism and churchplanting but also through various kinds of civic activity.

Any discussion of religion as a social force must make reference to secularisation theory and current debates on post-secular societies. Until recently, European cities were considered secular territory, reflected in dwindling congregations, religious buildings lying derelict or used for secular purposes, and the withdrawal of religion from the public square. However, the recent resurgence of religious movements and communities in the West challenges the 
assumption that cities are centres of secular modernity. This has generated widespread debates within the academy over whether societies are secularising or whether religion retains a significant role in modern social life (Baker and Beaumont 2011; Bartolini et al. 2017; Beckford 2012; Cady 2014; McLennan 2010; Wilford 2010). Indeed, some scholars are now writing about post-secular cities and societies (e.g. Baker and Beaumont 2011; Beaumont 2010; Habermas 2008). According to Justin Beaumont (2010:6), the postsecular refers to "the limits of the secularization thesis and the ever-growing realization of radically plural societies in terms of religion, faith and belief within and between diverse urban societies". Alongside processes of secularisation, we are witnessing the reemergence of religion as a social force in Europe, reflected in the growing significance of faith-based welfare provision, the impact of new places of worship on urban spaces, and the growth of Pentecostal and Islamic communities (Baker and Beaumont 2011; Dinham and Lowndes 2009). In London, Pentecostal resurgence is largely due to the presence of black Africans and Caribbeans who account for a third of the city's churchgoers (Brierley 2014).

Linda Woodhead and Paul Heelas (2000:307-308) identify three varieties of the secularisation approach. The first is the disappearance thesis, which holds that religion is destined to fade away in modern societies (see, for example, Bruce 1995). Arguing against the secularisation thesis in the sense of the disappearance of religion, many sociologists speak rather of a transformation of religion (Davie 2015; Hervieu-Léger 2000). Outside the walls of the mainline churches, religion seems to flourish in many ways, especially in forms that emphasise individual experience, including the various expressions of Pentecostalism. A second approach is the so-called differentiation thesis, which holds that religion gets pushed out of the public domain while remaining of some significance in private life(Wilson 1982). A third variety, called de-intensification theory by Woodhead and Heelas, is that religion remains but in a weakened form (Davie 1994).

Discussion of the significance of reverse mission churches in relation to secularisation must remain modest in its claims. The remainder of the chapter examines whether the reverse mission activities of Nigerian megachurches provides evidence of the re-emergence of religion as a social force in Britain. Does their presence in Britain support the idea that in certain European contexts religion may be gaining rather than losing strength in modern times? Woodhead and Heelas refer to this as sacralisation theory and identify three sub-theses: growth (by way of conversion), dedifferentiation (or deprivatisation) and intensification, corresponding to the three sub-theses of secularisation theory outlined above. I understand the concept of 'social force' in relation to migrant churches as having three possible dimensions. The first is the social impact on members' lives in terms of capacity to shape the migration process, 
determine levels of religious participation, influence socio-economic mobility, and motivate civic activity. The second dimension is the social impact on the wider society through the activities of religious organisations and persons resulting in individual conversions, church growth and social transformation. The final dimension associates social force with the 'de-privatization' of religion and its visibility in public space (Casanova 1994).

\section{5}

Migration, Religious Participation and Empowerment

Scholars of religious transnationalism have drawn attention to the resources religion provides in driving and sustaining migration (e.g. Adogame and Weissköppel 2005; Hagan and Ebaugh 2003; Levitt 2001; Ter Haar 2001; Vertovec 2000). African Pentecostal churches are especially important in this respect. One reason for their popularity is the way their social and religious support networks assist African Pentecostals to negotiate the migration process. This is important in immigrant contexts where people are separated from extended family networks. As Gerrie Ter Haar (1998: 43) notes, diasporic churches "contribute significantly to the material and immaterial well-being of African migrants", especially those living in urbanised areas of Western Europe.

In their theory of secularisation based on existential security, Pippa Norris and Ronald Inglehart (2004: 18) argue that the experience of growing up in less secure (i.e. poorer) societies heightens the importance of religious values. However, the conditions of greater security associated with developed nations can lead to a decline in religious participation. For many African Pentecostal migrants, Britain is an insecure environment despite its post-industrial status. While they hope for a better life, they often encounter difficulties, ranging from financial problems and unemployment to immigration difficulties and racial discrimination. In the case of Nigerian Pentecostals, they also have to contend with a perception of Nigerians by white Europeans as prone to corruption and criminality. One Nigerian pastor explained it thus:

The reason for that maybe where we are coming from and what we've gone through and why we've had to come closer to Christ.... It's almost like a home away from home, like a community away from home. Because once you find yourself here you don't have the support network that you once knew back at home. Therefore, the church becomes a form of support network. ${ }^{15}$ 
In contrast to current religious trends in Britain, where there has been a marked decline in church attendance (Brierley 2014; Goodhew 2012), congregational life remains an important expression of African Christian faith in the diaspora, a means of offsetting the pressures of individualism and fragmentation in Western society. Thus, Grace Davie's (1994) portrayal of religious trends in Britain in terms of a persistence of religious belief over against a decline in religious belonging does not apply to Nigerian Pentecostals for whom believing and belonging generally go hand in hand. Churches provide contexts for communal worship and prayer as well as social interaction with those who share similar culture and customs, thus contributing to the stocks of social and cultural capital necessary for successful integration. African diasporic churches are places where vital information about travel, employment, education, housing, immigration, and healthcare is freely circulated (Adogame 2013: 117). Nigerian churches organise seminars on such topics as business management, investment, immigration issues, marriage, and health awareness. Prayer in particular is considered an important resource for Nigerian migrants. Most churches have regular prayer meetings, which provide opportunity for people to receive prayer for particular needs, whether immigration issues, financial and health problems, or family relationships.

Small groups are another feature of Nigerian churches in Britain. Studies suggest that small groups encourage greater levels of religious participation and enable megachurches to become embedded in local communities (Chong and Goh 2015; Dougherty and Whitehead 2011; Thumma and Bird 2015b). Many Nigerian congregations have cell groups to provide pastoral care for members. Some of the larger churches also have interest groups to cater for the needs of different categories of people. For example, Jesus House's interest groups include a women's ministry, a men's fellowship, a youth church, a lone parent fellowship, a parenting group, a dance club, a cooking club, a business fellowship, a civic awareness group, and a football club. ${ }^{16}$ It operates a 'free market system' that allows members to choose which groups to join or gives them the option to start new groups. This seems to support a cultural market explanation of megachurch growth, which explains the growth of megachurches in terms of their ability to cater for the interests of religious consumers (Ellingson 2016). Small groups also function as socialisation mechanisms, inculcating Christian virtues and protecting adherents from the corrosive effects of Western liberal values deemed responsible for such societal vices as family breakdown, domestic abuse, sexual promiscuity, and youth crime.

16 Jesus House, “Interest Groups”, http://jesushouse.org.uk/life-groups/interest-groups. 
Another characteristic of Nigerian Pentecostal churches is their holistic concept of salvation, which includes not only holiness, but healing, deliverance and prosperity. The appeal of these theologies is obvious in a hostile economic environment like Africa, where access to medical facilities and to state funds is severely restricted, and adverse circumstances are often blamed on the activities of malevolent spirits. They are also popular among African migrants in Britain, who sometimes find it difficult to support their families, especially if they are students or low-paid workers without recourse to public funds. As Ogbu Kalu (2008: 288) reminds us, immigrants retain the spiritual worldview of their indigenous cultures and find Pentecostal churches "attentive to their deeply felt needs". One Nigerian pastor put it like this:

We preach the whole gospel.... But at times African-based churches tend to sway towards success and prosperity because of our background ... maybe because we have been disadvantaged before; maybe because we have been poor before.... When you look at our congregations in the Western world, you discover the majority are migrants. So right now they are struggling, so they need faith for them to come up. ${ }^{17}$

Perhaps more surprising is the continuing appeal of deliverance theology. Despite the influence of secularisation, issues such as witchcraft continue to be a reality for Africans in the diaspora. Deliverance theology is popular because it is practical and progressive in orientation, enabling Africans to break free from social and religious ties considered a hindrance to personal development. African diasporic churches hold regular programmes, which provide ritual settings for the promotion of healing, deliverance and prosperity teaching. For example, MFM's holds a monthly deliverance programme called "Power Must Change Hands" and RCCG's Victory House in London hosts an annual "Healing and Deliverance Week". Often speakers from Africa and the USA are invited to these events, reflecting the transnational nature of African Pentecostal churches.

Nigerian Pentecostal churches are also committed to building members' capacity to influence society. This is reflected in some of the mottos adopted by individual congregations, such as "Empowering lives, influencing society for Christ" and "Manifesting expectations, impacting society", and their promotion of success-oriented theologies through sermons, conferences, magazines and electronic media (Bremner 2016; Burgess 2011). As well as providing contexts for spiritual empowerment, churches organise seminars on business

17 Interview, 30/09/10. 
management, investment, marriage, job skills and British culture. One of the strengths of African Pentecostal churches is their internal organisation which is designed to mobilise the laity. Miller and Yamamori (2007: 184-186) refer to this as "giving ministry to the people" and suggest that it is a feature of the relatively flat organisational structure characteristic of many successful Pentecostal churches, where the role of the pastor and his or her associates is not to "do the ministry of the church, but to enable others to do this work". The RCCG seems to fit this pattern, with its combination of strong leadership at the top and a highly active laity. Ukah (2005: 330) describes it as a "laity-driven church", where individuals are empowered to pursue their vision without too much hindrance from bureaucracy. The RCCG's creation of a category of lay leaders, called 'workers', is innovative in terms of African Pentecostal ecclesiology. 'Workers' are members who have undergone a four-month period of training, enabling them to fulfil various practical roles in the church while continuing in their secular occupations. For example, Jesus House London has a volunteer workforce of around 650 members, serving in various departments in the church as well as in the local community. ${ }^{18}$

\section{Church Growth and Social Engagement}

In terms of church growth, the statistics for Nigerian Pentecostal churches are impressive. The largest independent Nigerian megachurch is Kingsway International Christian Centre (KICC), which claimed a congregation of 12,000 until it was forced to relocate because of the planned redevelopments for the London 2012 Olympics (Garbin 2013). KICC was founded in 1992 by Matthew Ashimolowo, who was originally sent as a missionary to London in 1984 by the Foursquare Gospel Church in Nigeria. In addition to its main congregation, which currently numbers 5,500 , it has planted eight branch churches in the UK and eleven in Nigeria, as well as branches in Ireland and several African countries (Effa 2013) $\cdot{ }^{19}$ Victorious Pentecostal Assembly, founded in 2005 by Alex Omokudu, boasts a regular attendance of 5,000 in its London headquarters, with branches in Bradford, Luton, Manchester, Birmingham and Dublin. ${ }^{20}$ Other independent Nigerian megachurches in London include Christ Faith Tabernacle (3,500 attendees), New Wine Church $(2,000)$ and Glory House $(2,000)$.

18 Jesus House 2010 Annual Report.

19 Kingsway International Christian Centre, "Branches", https://www.kicc.org.uk/branches/.

2o Victorious Pentecostal Assembly, "Pastor Alex Okokudu", http://vpachurch.org/pastoralex-omokudu/. 
Megachurch transplants from Nigeria have also experienced significant church growth. The fastest-growing Pentecostal denomination in Britain is the Redeemed Christian Church of God (RCCG) which planted its first congregation in 1988. By 2010, there were over 440 branches, with approximately 85,000 members. ${ }^{21}$ By 2016, this had increased to over 700 branches, of which 266 (40 percent) were located in London (Adedibu 2016). RCCG's largest congregation $(3,000)$ is Jesus House London. ${ }^{22}$ It was started in 1994 by Tony Rapu, senior pastor of RCCG's Apapa parish in Lagos, who was sent to London as a missionary (Burgess 2012). Other fast-growing RCCG congregations in London include Victory House which was attracting 700 attendees within 10 years of its inauguration, ${ }^{23}$ and Trinity Chapel, whose average annual attendance grew from 245 to 889 between 1999 and $2006 .{ }^{24}$ Some of the larger RCCG congregations have themselves planted multiple branches. ${ }^{25}$ Other megachurch transplants from Nigeria have founded multiple congregations in Britain including Deeper Life Bible Church (66), ${ }^{26}$ MFM (97), ${ }^{27}$ Christ Embassy (20), ${ }^{28}$ and Winners' Chapel (14). ${ }^{29}$ Winners' Chapel London claimed a congregation of 3,000 before its relocation to Dartford, Kent, in 2011.

However, these statistics tell only part of the story. An important component of the reverse mission discourse is the ambition to win converts from the host society. This is seldom the reality, as researchers in different contexts have found (Freston 2010; Hanciles 2008; Währisch-Oblau 2009). While African diasporic churches might (re)present themselves as cosmopolitan Christians open to other ethnicities, and direct their activities accordingly, they frequently end up catering for their fellow Africans instead. As Garbin (2013: 680) notes, a tension exists among Afro-Christian churches "between the 'openness' of a 'cosmopolitan rhetoric' and the 'closure' of a tendency for ethnic encapsulation".

21 The Redeemed Christian Church of God United Kingdom Directory of Parishes 2010, London: The Redeemed Christian Church of God UK, 2010.

22 Figure supplied by the senior pastor of Jesus House during the church's Annual Review (26/04/og).

23 Interview, Pastor Leke Sanusi, Victory House, 12/10/08.

24 Information supplied by the administrator of Trinity Chapel, 26/05//11.

25 For example, Jesus House London has planted 18 churches in the UK and Royal Connections planted 24 branches in the UK, Ireland, Sweden, Denmark, Finland (between 1997 and 2007). Jesus House. The Journey So Far, Annual Report 2016; Royal Connections magazine, Special Anniversary Edition, May 2007.

26 Deeper Life Bible Church, "Church Locations and Addresses", http://dclm-liverpool.org. uk/DCLMUK/CHURCH\%2oLOCATIONS\%20AND\%20ADDRESSES.pdf

27 http://www.mountainoffire.org.uk/index.php/branches.

28 http://www.ceintl.org/locate-a-christ-embassy/.

29 Winners' Chapel, European Church Network, http://www.winners-chapel.org.uk/lon don/index.php. 
Despite their multicultural aspirations, the social composition of Nigerian Pentecostal churches in Britain has remained predominantly African. Afe Adogame (2005: 508) identifies a "lack of cross-cultural appeal" and the tendency of African migrants to interact mainly with fellow Africans as the main barriers towards the realisation of a multi-racial group. Nigeria's global reputation for corruption and criminal activity, and the perception of African churches by white Europeans as institutions obsessed with money and the activities of evil spirits are also barriers to the formation of cosmopolitan congregations. To overcome this, some churches have intentionally adapted their theology and ritual practices in their host society, for example by adopting more Western styles of worship and toning down their emphasis on prosperity and deliverance (Burgess 2012).

Social action has also helped to overcome this barrier, enabling churches to make meaningful connections with local communities. As I have suggested, the reverse missionary agenda of Nigerian Pentecostals has driven some churches to engage in social initiatives in the wider society. Rather than reinforcing the image of Nigerians as economic migrants, or as prone to corruption and criminality, they are rebranding themselves as social campaigners contributing to the betterment of their neighbourhoods. There is considerable diversity among Nigerian Pentecostal churches in terms of social outreach. Many are minimally engaged, either due to a particular orientation that favours evangelism over social action or because they lack the necessary resources. Others are involved in a wide spectrum of social initiatives. One example is Jesus House London, whose social initiatives include the Novo Centre (a dropin centre for residents of a local housing estate), Jesus House Prison Ministry, the Manna Project (a food distribution centre), Abigail's Court (an outreach to the elderly), a Christians Against Poverty (CAP) debt counselling centre, and a Christmas homeless shelter (Burgess 2009). ${ }^{30}$ Another example is KICC whose community initiatives include a befriending service to residents in homeless hostels, a prison ministry, and a food bank called 'Noah's Ark' (Cartledge et al 2019). ${ }^{31}$ The majority Nigerian Pentecostal social initiatives are focused on social service provision rather than social justice issues such as racism and inequalities in the UK's educational, health and prison systems. An exception is KICC's "Breaking Educational Barriers" programme which partners with universities to address educational inequalities within the BAME community. ${ }^{32}$

$30 \quad$ Ayo Adedoyin, "Impacting the Community", Heart \& Soul Conference, Jesus House, 6 July 2012; Impact. Showing the Love of Christ in a Practical Way, Issue 01, September 2010 "KICC Community Initiatives \& Outreaches", https://www.kicc.org.uk/church/commu nity-initiatives/.

32 Elizabeth Pears, "Oxbridge calls: Breaking barriers in education", The Voice, gth February 2013, http://www.voice-online.co.uk/article/oxbridge-calls-breaking-barriers-education. 
The focus on social engagement has partly been a response to the difficulties Nigerian Pentecostals have encountered in Britain, where people are increasingly unreceptive to traditional evangelistic techniques and reluctant to attend church (Davie 2015). It is also a response to the Charity Commission's public benefit test, which requires religious institutions to engage in social action if they are to receive the tax benefits of charitable status. The turn to social action has also coincided with a change in public policy. Since the mid-199os, successive governments have recognised the potential of faith groups to contribute to social capital and welfare provision, especially in urban contexts. The significance of faith-based social action has increased since the climate of public sector austerity brought about by the economic downturn (Dinham and Jackson 2012; Dinham and Lowndes 2009; Furbey and Macey 2005). However, from the perspectives of Nigerian Pentecostals themselves, social action is an expression of the church's commitment to the biblical mandate to love one's neighbour by addressing the social needs of the wider society. For example, the senior pastor of Jesus House London refers to the church's duty "to show the love of God in a practical way" through prayer, charitable giving and participation in social welfare programmes. ${ }^{33}$ Transnational connections have also influenced Nigerian Pentecostal social engagement in the diaspora, especially developments in Nigeria, where Pentecostal social action has expanded in response to neoliberal reforms and the withdrawal of the state from welfare provision (Burgess 2011). One example is the London Lighthouse, whose "Touching the Community" initiative includes a community youth club, a food bank, a CAP debt counselling service, and arts events open to the public. ${ }^{34}$ The London Lighthouse is a church plant of House on the Rock, a megachurch in Lagos with a regular attendance of around 7,00o. House on the Rock's core values, which include a commitment to 'social responsibility', are displayed on the websites of the London and Lagos congregations and in the London Lighthouse's foyer. Its social initiatives in Lagos, which include a mobile health clinic, a ministry to drug addicts and gang members, a prison ministry, and a feeding programme for the poor, come under the umbrella of the Rock Foundation, a faith-based NGO committed to 'social reformation' among the 'underprivileged' 35

\footnotetext{
33 Agu Irukwu, "In the Crucible with Pastor Agu. Our Corporate Social Responsibility," Outflow (October 2008), 5 .

34 London Lighthouse, "Touching the Community", http://www.touchingthecommunity. org.uk/.

35 “History Of The Rock Foundation - Paul Adefarasin", September 19, 2016, https://believersportal.com/history-rock-foundation-paul-adefarasin/.
} 
This brings us to the final dimension of social force, the 'de-privatisation' of religion and its visibility in the public sphere. Social engagement has enabled some churches to gain public recognition at local and national levels, resulting in a number of high profile visits from politicians and royalty, the most famous being those of the Prince of Wales to the RCCG's Jesus House in 2007 and of David Cameron, the former British Prime Minister to RCCG's 'Festival of Life' prior to the 2015 general elections. Large religious events, such as the 'Festival of Life' and KICC's 'International Gathering of Champions' (IGOC), both held at a major conference centre in London, have raised the public profile of Nigerian Pentecostals churches.

Church buildings also provide congregations with a measure of visibility in urban space. In some areas of London, the religious landscape is littered with Nigerian churches, occupying a variety of secular and religious spaces. Whilst many smaller congregations remain invisible to the public, others have acquired their own buildings and used the media to create publicity for themselves. These are usually those with large memberships or with strong transnational ties to Nigeria, enabling them to generate sufficient financial capital. In their search for a permanent place of worship, African diasporic churches often have to move from place to place, which seriously hampers their organisational structures, their numerical growth, and their capacity for community engagement (Burgess 2009; Krause 2008; Ter Haar 2001). One example is the London Lighthouse which relocated many times before eventually purchasing a former Church of England building, which it renamed the Rock Tower. Formerly invisible in the public sphere due to its mobile existence, the church's acquisition of the Rock Tower has enabled it to reposition itself in relation to neighbouring churches as well as secular institutions and political actors. The church is now a recognised as an important ecumenical partner. The Rock Tower is also used to host political events, including Jeremy Corbyn and his supporters before and after his election as the Labour Party leader. ${ }^{36}$

Nigerian Pentecostals have also gained public visibility by their use of mass media, and especially the worldwide web. Internet presence encourages organisational cohesion on a local, national and international level as well as recognition within the public sphere. Many congregations in the UK have their own websites, which often mirror the websites of their mother churches in Nigeria. These are used for evangelistic purposes to attract new converts, to

36 John Gulliver, "Jeremy Corbyn drew huge crowds to the Rock Tower", Campden New Journal, 11 September, 2015, http://www.camdennewjournal.com/johngcorbyn. 
propagate prosperity and deliverance doctrines, and to provide information for current and prospective members. The Internet is also used by churches to articulate their social vision and advertise their social ministries. Some of the larger megachurches, such as KICC and RCCG, have their own satellite television channels. Nigerian Pentecostal megachurches have been receiving attention, both positive and negative, in the national media. Nigerian Pentecostal churches have been commended as dynamic and fast-growing in a context where mainstream Christianity in Britain is declining. ${ }^{37}$ But they have also been linked to financial misconduct, and human rights infringements connected with witchcraft accusations, deliverance practices, and so-called 'gay cure' therapies. KICC, Winners' Chapel and Christ Embassy have all been investigated by the Charity Commission for financial mismanagement. ${ }^{38}$ In the wake of controversies over child witchcraft accusations involving African Pentecostal churches, MFM has received criticism in the media for its deliverances practices associated with witchcraft beliefs. ${ }^{39}$ The quest for worship space by Nigerian megachurches in London has also attracted some negative publicity. Urban competition between religious and secular groups over scarce property and land resources in London has resulted in a number of high profile planning disputes being played out in the media. The most notable example is KICC, whose 2009 application for an 8,000-seat megachurch (inspired by American megachurch models) on an industrial estate in a predominantly white London suburb was refused on the grounds that the site was already allocated for industry (Garbin 2013; Greed 2016).

37 Damian Arnold, "African megachurch brings Gospel back to Britain with a dazzle", The Times, 21 November 2015, https://www.thetimes.co.uk/article/african-megachurch-bringsgospel-back-to-britain-with-a-dazzle-b8bhr8x23nk.

38 L. Peek, "Prosperity is the Promise of God", The Times, 17 March, 2003; Robert Booth, "Preacher faces scrutiny from Charities Commission over church's finances", Guardian, 15 August 2013, https://www.theguardian.com/society/2013/aug/15/bishop-oyedepo -church-charities-commission; Olivia Goldhill, "Pentecostal church investigated by the Charity Commission", The Telegraph, 16 August 2013, https://www.telegraph.co.uk/news/ religion/10246767/Pentecostal-church-investigated-by-the-Charity-Commission.html.

39 Josh Parry, "Who are the Mountain of Fire and Miracles Ministries? Gay 'cure' church one of thousands", Liverpool Echo, 4 September 2017, https://www.liverpoolecho.co.uk/news/ liverpool-news/who-mountain-fire-miracles-ministries-13468115; Adam Barnett, "Campaigners against witchcraft-promoting preacher's ExCel Appearance”, Newham Recorder, 16 September 2016, http://www.newhamrecorder.co.uk/news/campaigners-against -witchcraft-promoting-preacher-s-excel-appearance-1-4699171. 
This chapter has explored the phenomenon of megachurches and 'reverse mission' with a particular focus on churches of Nigerian provenance. Nigeria hosts some of the largest Pentecostal churches in the world with multiple national and international branches. Nigerian Pentecostals have also founded some of the largest churches in Europe. Some are branches of churches that originated in Nigeria; others are independent churches planted by Nigerian missionaries. One feature that distinguishes Nigerian megachurches from their American counterparts is their involvement in transnational networks which seek to replicate the success of their mother churches (Richardson 2017). Nigerians make up one of the largest transnational African communities in Britain, mainly due to Nigeria's status as Africa's most populous nation and its historic links to Britain. This has facilitated the emergence and growth of Nigerian Pentecostal churches in Britain initially as a means of catering for their members who had migrated for economic reasons. Explaining the growth of megachurches is an important issue discussed in the literature (Ellingson 2016). The chapter has identified a number of factors which have contributed to the growth of Nigerian Pentecostal churches in Britain. These include their function as social and religious support networks for African migrants, their charismatic style of leadership, their emphasis on lay ministry, their employment of small groups, their affective worship styles, their promotion of healing and success-oriented theologies, their use of media technologies, and their holistic approach to mission, which includes evangelism, church-planting and social action.

As we have seen, the rhetoric of reverse mission employed by Nigerian Pentecostals is influenced by their experience of religious vitality back home and their location in Britain's post-Christian urban spaces. The symbolic maps drawn by Nigerian Pentecostals, which depend upon a particular conception of Britain as a former missionary nation turned mission field, have driven them to embark on programmes of territorial expansion not only through evangelism and church-planting but also through social action. Thus, the adoption of a broader conception of mission, which includes social engagement, enables a more positive evaluation of the achievements of African diasporic churches than has generally been the case in studies of reverse mission.

Does the presence of Nigerian Pentecostal churches challenge the secularisation paradigm in Britain? This study can provide only a tentative answer to this question. However, I suggest that to some extent they are an indication of the re-emergence of religion as a social force. Their presence has raised levels of religious participation among Nigerian (and other African) Christians by providing contexts for worship, prayer and social interaction with those who share 
similar culture and customs, thus assisting immigrants to negotiate the migration process and become incorporated into the host society. In some cases, their organisational structures and empowerment programmes have generated volunteers for community engagement. In terms of church growth, some of the largest congregations in Britain are led by Nigerians. Furthermore, churches such as the RCCG have been particularly successful in planting new congregations which has raised their visibility in Britain's urban spaces. However, despite their aspirations to build multi-ethnic congregations, Nigerian Pentecostals have generally failed to make converts from the indigenous British population or from other ethnic minority groups. Their focus on social engagement is to be commended, but further research is needed to assess the impact of these initiatives on the wider society. Currently, the majority of congregations are small which makes it difficult for them to engage in social action. However, some of the larger churches have gained public recognition for their work in the community. Their visibility has also been enhanced as they have acquired their own buildings and used the media to create publicity for themselves.

\section{References}

Adedibu, B. 2012. Coat of Many Colours: The Origin, Growth, Distinctiveness and Contributions of Black Majority Churches to British Christianity. Gloucester: Wisdom Summit.

Adedibu, B. 2016. "Missional History and the Growth of the Redeemed Christian Church of God in the United Kingdom (1988-2015)." Journal of the European Pentecostal Theological Association. 36:1, 80-93.

Adogame, A. 2005. "African Communities in Diaspora." In O.U. Kalu, ed, African Christianity. An African Story. Pretoria: University of Pretoria, 494-514.

Adogame, A. 2013. The African Christian Diaspora. New Currents and Emerging Trends in World Christianity. London/New York: Bloomsbury.

Adogame A. and Weissköppel, C. 2005. "Introduction: Locating Religion in the Context of African Migration." In A. Adogame and C. Weissköppel, eds, Religion in the Context of African Migration. Bayreuth: Breitinger, 1-22.

Asamoah-Gyadu, J.K. 2005. "An African Pentecostal on Mission in Eastern Europe: The Church of the 'Embassy of God' in the Ukraine." Pneuma: The Journal of the Society for Pentecostal Studies. 27:2, 297-321.

Asamoah-Gyadu, J.K. 2015. "Doing Greater Things: Megachurch as an African Phenomenon." In J.D. James, ed, A Moving Faith: Megachurches Go South. India: Sage Publishing, 43-56.

Bartolini, N., Chris, R., MacKian, S. and S. Pile 2017. "The Place of Spirit: Modernity and the Geographies of Spirituality." Progress in Human Geography. 41:3, 338-354. 
Beaumont, J. 2010. “Transcending the Particular in Postsecular Cities". In A.L. Molendijk, J. Beaumont and C. Jedan, eds, Exploring the Postsecular: The Religious, the Political and the Urban. Leiden: Brill, 3-17.

Beaumont, J. and Baker, C. 2011. "Introduction: The Rise of the Postsecular City." In J. Beaumont and C. Baker, eds, Postsecular Cities. Space, Theory and Practice. London: Continuum, 1-14.

Beckford, J. A. 2012. "SSSR Presidential Address Public Religions and the Postsecular: Critical Reflections." Journal for the Scientific Study of Religion. 51:1, March, 1-19.

Bird, W. 2017. "The World's Largest Churches. A Country-By-Country List of global Megachurches." retrieved October 15th 2017 from leadnet.org/world.

Bird, W. and. Thumma, S. 2011. "A New Decade of Megachurches 2011. Profile of Large Attendance Churches in the United States." Hartford Institute for Religious Research.http://www.hartfordinstitute.org/megachurch/New-Decade-of-Megachurches2011Profile.pdf.

Bremner, S. 2016. "Black Majority Megachurches in London: Aspiring to Engender Change." Unpublished paper. Megachurches and Social Engagement in London Project, November, $1-8$.

Brierley, P. 2014. UK Church Statistics, Number 2, 2010 to 2020. Tonbridge: ADBC Publishers.

Bruce, S. 1995. Religion in Modern Britain. Oxford: Oxford University Press.

Burgess, R. 2009. "African Pentecostal Spirituality and Civic Engagement: The Case of the Redeemed Christian Church of God in Britain." Journal of Beliefs and Values. 30:3, 255-273.

Burgess, R. 2011. "Bringing Back the Gospel. Reverse Mission among Nigerian Pentecostals in Britain." Journal of Religion in Europe. 4:3, 429-449.

Burgess, R. 2012. "African Pentecostal Growth: The Redeemed Christian Church of God." In D. Goodhew, ed, Church Growth in Britain. 1980 to the Present. Farnham: Ashgate, 127-144.

Burgess, R., Knibbe, K and A. Quaas 2010. "Nigerian-initiated Pentecostal Churches as a Social Force in Europe: The Case of the Redeemed Christian Church of God." PentecoStudies. 9:1, 97-121.

Cady, L.E. 2014. "Public Theology and the Postsecular Turn." International Journal of Public Theology. 8:3, 292-312.

Cartledge, M. J., S. Dunlop, H. Buckingham, and S. Bremner. 2019. Megachurches and Social Engagement: Public Theology in Practice. Leiden: Brill.

Casanova, J. 1994. Public Religions in the Modern World. Chicago, London: University of Chicago Press.

Catto, R. 2008. "From the Rest to the West. Exploring Reversal in Christian Mission in Twenty-first Century Britain." PhD. University of Exeter.

Chambers, P. 2006. "Sacred Landscapes, Redundant Chapels and Carpet Warehouses. The Religious Heritage of South West Wales." In E. Arweck and W. Keenan, eds, 
Materializing Religion. Expression, Performance and Ritual. Aldershot: Ashgate, $37-47$.

Chong, T. 2015. "Megachurches in Singapore: The Faith of an Emergent Middle Class." Pacific Affairs. 88:2, 215-235.

Chong, T. and Goh, D. 2015. "Asian Pentecostalism." In B.S. Turner and O. Salemink, eds, Routledge Handbook of Religions in Asia. London and New York: Routledge, 412-415.

Davie, G. 1994. Religion in Britain since 1945. Oxford: Blackwell.

Davie, G. 2015. Religion in Britain. A Persistent Paradox. Chichester: Wiley Blackwell

Dinham, A. and Jackson, R. 2012. "Religion, Welfare and Education." In L. Woodhead and R. Catto, eds, Religion and Change in Modern Britain. London/New York: Routledge, $272-298$.

Dinham, A. and Lowndes, V. 20og. "Faith and the Public Realm." In A. Dinham, R. Furbey and V. Lowndes, eds, Faith in the Public Realm. Controversies, Policies and Practices. Bristol: The Policy Press, 1-20.

Dougherty, D. and Whitehead, A.L. 2011. "A Place to Belong: Small Group Involvement in Religious Congregations." Sociology of Religion. 72:1, 91-111.

Eade, J. 2017. "Creating Religious Homes in London: Sacralising Space in a Deeply Globalised City." In F. Guesnet, C. Laborde and L. Lee, eds, Negotiating Religion: Crossdisciplinary Perspectives. London: Routledge, 151-168.

Effa, A.L. 2013. "Releasing the Trigger: the Nigerian Factor in Global Christianity." International Bulletin of Missionary Research. 37:4, 214-218

Ellingson, S. 2016. "New Research on Megachurches. Non-denominationalism and Sectarianism”. In B.S. Turner, ed, The New Blackwell Companion to the Sociology of Religion. Chichester: Wiley Blackwell, 247-266.

Fath, S. 2008. Dieu XXL: La Révolution des Megachurches. Paris: Autrement.

Freston, P. 2010. "Reverse Mission: A Discourse in Search of Reality?" PentecoStudies. 9:2, 153-74.

Furbey, R. and Macey, M. 2005. "Religion and Urban Regeneration: A Place for Faith?" Policy and Politics. 33:1, 95-116.

Garbin, D. 2013. "Visibility and Invisibility of Migrant Faith in the City: Diaspora Religion and the Politics of Emplacement of Afro-Christian Churches." Journal of Ethnic and Migration Studies. 39:5, 677-696.

Gerloff, R. 2000. "The Significance of the African Christian Diaspora in Europe." International Review of Mission. 89:354, 498-510.

Gifford, P. 2004. Ghana's New Christianity. Pentecostalism in a Globalising African Economy. London: Hurst \& Company.

Gifford, P. 2015. Christianity, Development and Modernity in Africa. London: Hurst \& Company.

Goodhew, D. 2012. "Church Growth in Britain, 1980 to the Present Day." In D. Goodhew, ed, Church Growth in Britain. 1980 to the Present. Farnham: Ashgate, 3-22. 
Gornik, M.R. 2011. Word Made Global: Stories of African Christianity in New York City. Grand Rapids, MI: Eerdmans.

Greed, C. 2016. "Christianity and Planning: Pentecostal Churches." Occasional Paper 1, March, 1-54.

Habermas, J. 2008. "Notes on Post-Secular Society." New Perspectives Quarterly. 25:4, $17-29$.

Hagan, J. and Ebaugh, H.R. 2003. "Calling upon the Sacred: Migrants' use of Religion in the Migration Process." International Migration Review. 37:4, 1145-1162.

Hanciles, J. 2008. Beyond Christendom. Globalization, African Migration, and the Transformation of the West. Maryknoll, NY: Orbis Books.

Harris, H. 2006. Yoruba in Diaspora. An African Church in London. Basingstoke: Palgrave MacMillan.

Hervieu-léger, D. 2000. Religion as a Chain of Memory. New Brunswick, NJ: Rutgers University Press.

James, J. D. 2015. “A Moving Faith: An Introduction.” In J.D. James, ed, A Moving Faith: Megachurches Go South. Washington D.C and Delhi: Sage, 1-18.

Johnson, T. M. 2013. "Global Pentecostal Demographics." In D.E. Miller, K.H. Sargeant and R. Flory, eds, Spirit and Power. The Growth and Global Impact of Pentecostalism. Oxford: Oxford University Press, 319-328.

Kalu, O.U. 2008. African Pentecostalism. An Introduction. Oxford: Oxford University Press.

Kim, R. 2016. "Evangelizing White Americans: Sacrifice, Race, and a Korean Mission Movement in America." Open Theology. 2:1, 668-68o.

Knibbe, K.E. 2010. "Geographies of Conversion: Focusing on the Spatial Practices of Nigerian Pentecostalism." PentecoStudies. 9:2, 175-194.

Koning, D. 2009. "Place, space, and authority. The mission and reversed mission of the Ghanaian seventh-day adventist church in Amsterdam." African Diaspora. 2:2), 203-226.

Krause, K. 2008. "Spiritual Spaces in Post-Industrial Places in North East London." In M. P. Smith and J. Eade, eds, Transnational Ties: Cities, Migrations, and Identities. New Brunswick: Transaction Publishers, 109-130.

Levitt, P. 2001. "Between God, Ethnicity, and Country: An Approach to the Study of Transnational Religion." Oxford: ESRC Transnational Communities Working Paper WPTC-01-13, 1-31.

Levitt, P. and Glick Schiller, N. 2004. "Conceptualizing Simultaneity: A Transnational Social Field Perspective on Society." International Migration Review. 38:3, 1002-1039.

Marshall, R. 2014. "Dealing with the Prince over Lagos': Pentecostal Arts of Citizenship." In M. Diouf and R. Fredericks, eds, The Arts of Citizenship in African Cities. Infrastructures and Spaces of Belonging. New York: Palgrave Macmillan, 91-114.

McLennan, G. 2010. “The Postsecular Turn.” Theory, Culture \& Society. 27:4, 3-20. 
Miller, D.E. and Yamamori, T. 2007. Global Pentecostalism. The New Face of Christian Social Engagement. Berkeley and Los Angeles, CA: University of California Press.

Norris, P. and Inglehart, R. 2004. Sacred and Secular. Religion and Politics Worldwide. Cambridge/New York: Cambridge University Press.

Obinna, E. 2014. "African Christians in Scotland: Contesting the Rhetoric of Reverse Mission." In G. Vincent and E. Obinna, eds, Christianity in the Modern World: Changes and Controversies. Farnham: Ashgate, 77-94.

Ojo, M.A. 2006. The End-Tie Army. Charismatic Movements in Modern Nigeria. Trenton, NJ: Africa World Press.

Ojo, M. A. 2007. “Reverse Mission." In J. Bonk, ed, Encyclopedia of Missions and Missionaries. New York/London: Routledge, $380-382$.

Olupona, J.K. and Gemignani, R. ed, 2007. African Immigrant Religions in America. New York and London: New York University Press.

Oro, A.P. 2014. "South American Evangelicals' Re-conquest of Europe." Journal of Contemporary Religion. 29:2, 219-232.

Osgood, H. 2006. "African Neo-Pentecostal Churches and British Evangelicalism 19852005: Balancing Principles and Practicalities." PhD, School of Oriental and African Studies, London.

Richardson, K. 2017. "Gospels of Growth: The American Megachurch." In D. Hempton and H. McLeod, ed, Secularization and Religious Innovation in the North Atlantic World. Oxford: Oxford University Press, 291-308.

Silva, A. and Rodrigues, D. 2013. "Religion, Migration and Gender Strategies: Brazilian (Catholic and Evangelical) Missionaries in Barcelona." Religion and Gender. 3:1, 42-59.

Smith, D.A. and Campos, L. S. 2015. "Concentrations of Faith: Megachurches in Brazil." In J.D. James, ed, A Moving Faith: Megachurches Go South. Washington D.C and Delhi: Sage, 169-190.

Ter Haar, G. 1998. Halfway to Paradise: African Christians in Europe. Cardiff: Cardiff Academic Press.

Ter Haar, G. 2001. African Christians in Europe. Nairobi: Acton Publishers.

Thumma, S. 1996. Exploring the Megachurch Phenomena: Their Characteristics and Cultural Context. Hartford Institute for Religious Research.

Thumma, S.L. and Bird, W. 2015a. "Megafaith for the Megacity: The Global Megachurch Phenomenon." In S. Brunn, ed, The Changing World Religion Map. Dordrecht: Spring Netherlands, 2331-2352.

Thumma, S.L. and Bird, W. 2015b. "Recent Shifts in America's Largest Protestant Churches: Megachurches 2015 Report.” Leadership Network and Hartford Institute for Religion Research, 1-20.

Thumma, S.L. and Travis, D. 2007. Beyond Megachurch Myths: What We Can Learn From America's Largest Churches (Vol. 21). John Wiley \& Sons. 
Udotong, W. 2010. "Transnational Migration and the Reverse Mission of Nigerian-led Pentecostal Churches in the U.S.A.: A Case Study of Selected Churches in Metro Atlanta." PhD, Asbury Theological Seminary.

Ukah, A. 2004. "Pentecostalism, Religious Expansion and the City: Lessons from the Nigerian Bible Belt." In P. Probst and G. Spittler, eds, Between Resistance and Expansion. Explorations of Local Vitality in Africa, New Brunswick (USA) and London (UK): Transaction Publishers, 415-443.

Ukah, A. 2005. "Mobilities, Migration and Multiplication. The Expansion of the Religious Field of the Redeemed Christian Church of God (RCCG), Nigeria." In A. Adogame and C. Weissköppel, eds, Religion in the Context of African Migration. Bayreuth: Bayreuth African Studies. 75, 317-341.

Ukah, A. 2009. "Reverse Mission or Asylum Christianity? A Nigerian Church in Europe." In T. Falola and A. Agwuele, eds, Africans and the Politics of Popular Cultures. Rochester, NY: University of Rochester Press, 104-132.

Ukah, A. 2014. "Redeeming Urban Spaces. The Ambivalence of Building a Pentecostal City in Lagos, Nigeria.” In J. Becker, K. Klingan, S. Lanz and K. Wildner, eds, Global Prayers. Contemporary Manifestations of the Religious in the City. Zürich: Lars Müller Publishers, 178-197.

Vermeer, P. 2015. "Church Growth and Appealing Sermons: A Case Study of a Dutch Megachurch." Journal of Empirical Theology. 28:1, 1-22.

Vertovec, S. 2000. "Religion and Diaspora." Oxford: ESRC Transnational Communities Working Paper WPTC-01-01, 1-45.

Von Der Ruhr, M. and Daniels, J.P. 2012. "Subsidizing Religious Participation Through Groups: A Model of the 'Megachurch' Strategy for Growth." Review of Religious Research. 53:4, 471-491.

Wade, M. 2016. "Seeker-friendly: The Hillsong Megachurch as an Enchanting Total Institution." Journal of Sociology. 52:4, 1-16.

Währisch-Oblau, C. 2009. The Missionary Self-Perception of Pentecostal/ Charismatic Church Leaders from the Global South in Europe. Bringing Back the Gospel. Leiden: Brill.

Wilford, J. 2010. "Sacred Archipelagos: Geographies of Secularization." Progress in $\mathrm{Hu}$ man Geography. 34:3, 328-348.

Wilson, B. 1982. Religion in Sociological Perspective. Oxford and New York: Oxford University Press.

Wimmer, A. and Glick Schiller, N. 2003. "Methodological Nationalism and Beyond: Nation-State Building, Migration and the Social Sciences." Global Networks. 2:4, 301-334.

Woodhead, L. and Heelas, P. 200o. Religion in Modern Times. Oxford: Blackwell Publishers. 